\title{
Uma contribuição para o crescimento da ciência no campo geriátrico e gerontológico nacional e internacional
}

\section{Acontribution tothegrouth of siencein thenetional andintemational fied of geriatricsandgerontdogy}

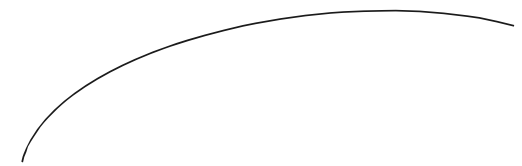

Para redigir este editorial, decidimos revistar os primeiros números da Série Textos sobre Envelbecimento, marco inaugural da trajetória que conduziu à Revista Brasileira de Geriatria e Gerontologia, que nos traz aos dias de hoje.

No ano de 1998, publicamos o primeiro volume com dois textos escritos por pesquisadores da equipe da UnATI-UERJ. Somente um ano depois veio a público o segundo volume, também com dois trabalhos de autoria de nossa equipe.

Em 2000, passamos a publicar dois volumes ao ano e excluímos a expressão "Série" do título da publicação, assumindo seus novos rumos: a construção de um periódico aberto à participação da comunidade científica. Divulgamos três artigos em cada número da revista nesse ano, passando a cinco textos por edição em 2002. Nos dois anos seguintes, foi aumentando o número de artigos publicados e novas seções foram criadas, indicando as perspectivas favoráveis que essa iniciativa contemplava para um futuro breve.

Em 2005, assumimos o desafio da periodicidade quadrimestral, em função do incremento na entrada de originais qualificados para divulgação, já oriundos de diversas áreas do conhecimento e de todo o território nacional.

Oito anos após seu nascimento, transformam-se os Textos sobre Envelhecimento na Revista Brasileira de Geriatria e Gerontologia, totalmente reformulada, ao mesmo tempo em que reafirmava seus preceitos fundamentais

A linha editorial seguirá os pressupostos básicos do trabalho bem-sucedido desenvolvido na UnATI nos últimos 13 anos, reconhecido como paradigma de modelo de cuidado integral à saúde. Dessa forma, nosso foco estará no debate, pesquisa, interdisciplinaridade, participação social, promoção, na assistência e reabilitação da saúde. Também compõem a grade de interesse os mais relevantes conceitos de Saúde Coletiva e de metodologia científica relacionados ao campo geriátrico e gerontológico. A concepção da Revista Brasileira de Geriatria e Gerontologia leva em conta o escopo e a complexidade do envelhecimento humano, reclamando uma superação dos modelos predominantes no País (VERAS, 2006). ${ }^{1}$

VERAS Renato. Revista Brasileira de Geriatria e Gerontologia. Rev. Bras. Geriatr. Gerontol. [periódico na Internet]. 2006 [citado 26 mar 2011]; 9(1): 5-6. Disponível em: http://revista.unati.uerj.br/scielo.php?script $=$ sci_arttext\&pid $=$ S1809-98232006000100001\&lng =pt. 
Segue a RBGG até 2010, crescendo em número de originais recebidos, recusados e publicados. Amplia-se o leque de origens geográficas dos trabalhos submetidos, alcançando a América Latina e a Europa. Além de indexações nacionais, como EDUBASE, insere-se a revista em bases internacionais como LILACS, LATINDEX e o Directory of Open Access Journals.

A partir de 2011, passaremos à publicação trimestral da RBGG. Mais um importante esforço que se mostra afinado com os rumos da ciência brasileira, em seu crescimento nacional e internacional. Esta é a nossa contribuição. 